\title{
ЯЗЫКОЗНАНИЕ
}

\section{Семантика цветообозначения хар 'черный' в фольклорном тексте: лингвокультурологический аспект (на примере калмыцких сказок в записи Г. Й. Рамстедта)}

\section{Александра Тагировна Баянова ${ }^{1}$}

${ }^{1}$ Калмыцкий научный центр РАН (д. 8, ул. И. К. Илишкина, 358000 Элиста, Российская Федерация) младший научный сотрудник iD 0000-0001-7718-802X. E-mail: ale-bayanova@yandex.ru

\author{
(C) КалмНЦ РАН, 2021 \\ (C) Баянова А. Т., 2021
}

\begin{abstract}
Аннотация. Введение. Настоящая статья посвящена анализу значения колоронима хар 'черный' в фольклорном тексте. Целью исследования является анализ семантики цветообозначения хар ‘черный’ с точки зрения лингвокультурологии. Материалом исследования послужили тексты калмыцких сказок, записанных Г. Й. Рамстедтом. Результатыл. На основе анализа выделено шесть оттенков черного цвета. Определена семантика лексемы хар 'черный'. Рассмотрены способы перевода исследуемой лексемы на немецкий язык.

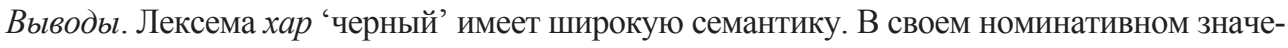
нии используется при обозначении цвета, масти животных, цвета кожи человека. В именах собственных он применяется в значении ‘крепкий, сильный’. Лексема хар 'черный’ может обозначать социальное положение человека: хар яста күн 'простолюдин' (букв. 'человек черной кости'). В большинстве случаев лексема хар 'черный’ имеет отрицательную коннотацию. Черным цветом обозначаются хтонические символы (хар иурх 'черная щука', хар темән 'черный верблюд’, ут хар күн ‘букв. длинный черный человек').
\end{abstract}

Ключевые слова: черный цвет, линговокультурология, семантика, калмыцкий язык, фольклорный текст, цветообозначение

Благодарность. Исследование выполнено при финансовой поддержке гранта в форме субсидии из федерального бюджета, выделяемой для государственной поддержки научных исследований, проводимых под руководством ведущего ученого (проект № 075-15-2019-1879 «От палеогенетики до культурной антропологии: комплексное интердисциплинарное исследование традиций народов трансграничных регионов: миграции, межкультурное взаимодействие и картина мира»).

Для цитирования: Баянова А. Т. Семантика цветообозначения хар 'черный' в фольклорном тексте: лингвокультурологический аспект (на примере калмыцких сказок в записи Г. Й. Рамстедта) // Монголоведение. 2021. Т. 13. № 1. С. 96-107. DOI: 10.22162/2500-1523-2021-1-96-107 


\title{
Semantics of the Color Term xap 'Black' in Folklore Texts: A Linguoculturological Aspect (A Case Study of Kalmyk Folktales Recorded by G. J. Ramstedt)
}

\author{
Aleksandra T. Bayanova ${ }^{1}$ \\ ${ }^{1}$ Kalmyk Scientific Center of the RAS (8, Ilishkin St., Elista 358000, Russian Federation) \\ Junior Research Associate
}

iD 0000-0001-7718-802X. E-mail: ale-bayanova@yandex.ru

(C) KalmSC RAS, 2021

(C) Bayanova A. T., 2021

\begin{abstract}
Introduction. The article analyzes semantic components and variants of the Kalmyk color term xap 'black' in folklore texts. Goals. The study investigates semantics of the color term xap 'black' in a linguocultural perspective. Materials. The work explores Kalmyk folktales recorded by the Finnish scholar G. J. Ramstedt during his scientific expedition to the Kalmyk Steppe. Results. The analysis reveals six shades of black and sums up its semantic constituents and variants. Special emphasis is laid on the applied Kalmyk-toGerman translation means. Conclusions. The lexeme xap 'black' is distinguished by extensive semantics. It serves to denote animal coat and human skin colors. In personal names, it has the meaning of 'strong, enduring'. The word can also identify an individual's social status, e.g., хар яста күн 'commoner' (lit. 'a black-boned man'). In most cases the lexeme xap 'black' contains negative connotations. The color black designates chthonian symbols (xap иурх 'black pike', хар темән 'black camel', ут хар күн lit. 'tall (long) black man').
\end{abstract}

Keywords: color black, linguoculturology, semantics, Kalmyk language, folklore text, color term

Acknowledgements. The reported study was funded by government grant in the form of federal budget subsidy aimed to support scientific research directed by the Leading Scientist - project name 'From Paleogenetics to Cultural Anthropology: Comprehensive Interdisciplinary Research of Peoples and Traditions of Cross-Border Regions - Migrations, Cross-Cultural Interactions and Worldviews' (state reg. no. 075-15-2019-1879).

For citation: Bayanova A. T. Semantics of the Color Term xap 'Black' in Folklore Texts: A Linguoculturological Aspect (A Case Study of Kalmyk Folktales Recorded by G. J. Ramstedt). Mongolian Studies (Elista). 2021. Vol. 13(1): 96-107. (In Russ.). DOI: 10.22162/2500-1523-2021-1-96-107

\section{Введение}

Черный цвет в калмыцкой культуре так же, как и во многих культурах других народов, являясь антиподом белого цвета, символизирует тьму, смерть, зло и т. д. По мнению Н. Л. Жуковской, черный цвет имеет у монголоязычных народов отрицательную коннотацию, с ним связано «все негативное (злое, темное, жестокое, несчастливое, профанное)» [Жуковская 2002: 203]. Черный цвет «вызывал суеверные страхи и представления о злых духах» [Кочешков 1973: 12].

В культурологическом аспекте слово хар имеет довольно широкую семантику. В калмыцко-русском словаре имеются следующие значения слова хар 'черный': 1. 1) черный, темный: хар керә 'черный ворон', хар шир 'черная краска’; 2) постный (в значении без молока), чистый (в значении без примесей): 
хар цуә (незабеленный чай), хар усн 'чистая вода'; 3) простой, простонародный: хар күн 'простолюдин, мирянин'; хар келн 'просторечный (разговорный) язык'; 4) черный, физически тяжелый: хар көдлмш 'черная (физически тяжелая) работа'; хар күчн 'физическая сила'; 5) дурной, скверный; вредный; порочный преступный: хар саната 'злонамеренный, коварный'; 6) самый сильный; самый...: хар киитн 'сильный холод'; хар салькн 'сильный (бесснежный) ветер'. 2. 1) очень, слишком: хар өрлә 'рано утром'; хар нетрусн 'тьма-тьмущая, видимо-невидимо’ [КРС 1977: 576-577].

Целью данной статьи является анализ семантики черного цвета на основе фольклорного текста.

\section{Материалы и методы}

Материалом исследования послужили сказки, записанные финским ученым Г. Й. Рамстедтом. Полевые записи сказок были изданы Г. Й. Рамстедтом на калмыцком и немецком языках в двух частях. Первая часть, опубликованная в 1909 г., состоит из 18 сказочных текстов [Kalmückische ... 1909]. Вторая часть книги, содержащая сказки под номерами 19-22 (с. 155-237), вышла в свет только в 1919 г. [Kalmückische ... 1919].

Так как данное исследование проводится на основе фольклорного текста, являющегося хранилищем культурной информации определенного этноса, фиксирующего «мир» той культуры, на языке которой он создан, то использовались метод лингвокультурологического анализа фольклорного текста, предполагающего анализ единиц художественного текста с точки зрения их национально-культурной семантики, и метод концептуального анализа с целью реконструкции национальной языковой картины мира.

\section{Диапазоны оттенков черного цвета в калмыцких сказках в записи Г. Й. Рамстедта}

Согласно исследованному фактическому материалу в анализируемых калмыцких сказках Г. Й. Рамстедта, лексема хар по частотности употребления занимает лидирующее положение - 144 словоупотребления, что составляет 32,4 \% от общего количества цветовой лексики.

Диапазон оттенков черного цвета варьирует от блестяще-черного до серо-рыжего (см. табл. 1).

Таблица 1. Шкала оттенков черного цвета (на материале сказок в записи Г. Й. Рамстедта)

[Table 1. Shades of black traced in Kalmyk folktales recorded by G. J. Ramstedt]

\begin{tabular}{|c|c|c|c|}
\hline № & Оттенки & Калмыцкий текст $^{1}$ & Перевод на русский язык² \\
\hline 1. & $\begin{array}{l}\text { блестяще- } \\
\text { черный }\end{array}$ & 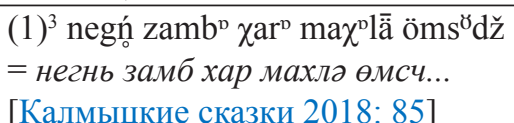 & $\begin{array}{l}\text { 'Один был в черной } \\
\text { шапке' }\end{array}$ \\
\hline
\end{tabular}

1 Здесь и далее переложение на современную калмыцкую графику дано по изданию «Калмыцкие сказки в записи Г. Й. Рамстедта: тексты и исследования». В 3 ч. Ч . ІІ. [Калмыцкие сказки 2018].

2 Перевод на русский язык осуществлен автором статьи.

${ }^{3}$ Примеры и их нумерация даны в скобках. 


\begin{tabular}{|c|c|c|c|}
\hline 2. & черный & 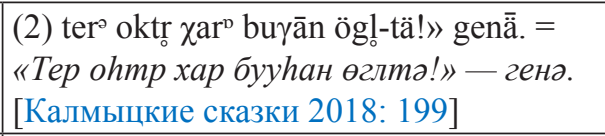 & $\begin{array}{l}\text { ‘ККороткоствольное } \\
\text { черное ружье дайте мне!» } \\
\text { - говорит’ }\end{array}$ \\
\hline 3. & $\begin{array}{l}\text { черно- } \\
\text { бурый }\end{array}$ & 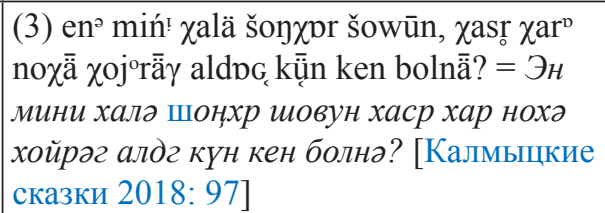 & $\begin{array}{l}\text { ‘«Этих моих кречет птицу } \\
\text { и охотничью черную } \\
\text { собаку что за человек } \\
\text { убил?’ }\end{array}$ \\
\hline 4. & бурый & 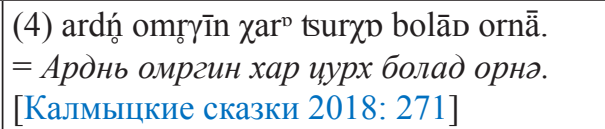 & $\begin{array}{l}\text { 'Следом бросился, } \\
\text { обернувшись огромной } \\
\text { черной щукой’ }\end{array}$ \\
\hline 5. & $\begin{array}{l}\text { темно- } \\
\text { серый }\end{array}$ & 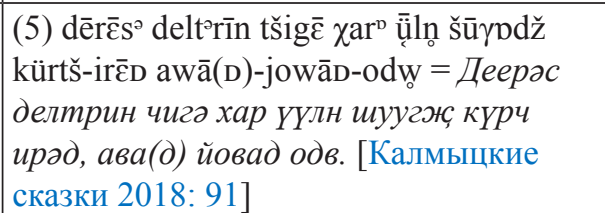 & $\begin{array}{l}\text { 'Сверху с подпотник } \\
\text { величиной черная туча с } \\
\text { шумом налетела и унесла } \\
\text { его' }\end{array}$ \\
\hline 6. & $\begin{array}{l}\text { серо- } \\
\text { рыжий }\end{array}$ & 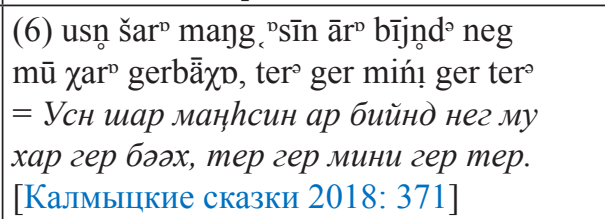 & $\begin{array}{l}\text { ‘«озади [жилища] Усун } \\
\text { Шара мангасов стоит } \\
\text { убогая черная кибитка, эта } \\
\text { кибитка и есть мой дом»’ }\end{array}$ \\
\hline
\end{tabular}

1. Из контекста сказки следует, что носил черную шапку человек, находившийся в услужении хана, и скорее всего он не был простолюдином. Как пишет И. А. Житецкий, «простонародье носит шапки, сделанные из сукна, нанки и пр.» [Житецкий 1893: 9]. Скорее всего, это была меховая шапка. Среди мужских шапок различали несколько ее видов: хазг махла 'казачья шапка' - самая распространенная, круглой формы; бучтә махла 'шапка с ушками'; тоориз махла 'женская шапочка'; хажсль махла 'четырехугольная шапка'. Для шапок использовали обработанную мерлушку - шкуру ягненка, причем забивали для этого детеныша курдючной овцы возрастом до месяца, так как стекловидный и первичный волосяной покров обладал особым свойством - блеском и имел мелкие кольцеобразные завитки, что служило дополнительным украшением головного убора. Мерлушка могла быть черного, белого и серого цветов. В данном контексте цвет шапки блестяще-черный. В немецком тексте автором использовано прилагательное schwarz 'черный':

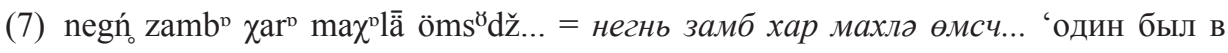
черной шапке...' - ...der andere hatte eine runde schwarze mütze aufgesetzt. ‘Другой надел круглую черную шапку’4 [Калмыцкие сказки 2018: 85].

2. Лексема $x a p$ в своем номинативном значении используется при обозначении цвета предметов: хар кевс 'черный ковер', хар бу 'черное ружье', хар маля 'черная плеть' и т. д. В немецком тексте используется прилагательное schwarz 'черный':

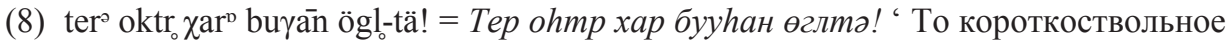
черное ружье дайте мне!' - ...gib mir jenes kurze schwarze gewehr! ‘Дай мне то короткоствольное черное ружье!’ [Калмыцкие сказки 2018: 199].

\footnotetext{
4 Здесь и далее перевод с немецкого на русский язык осуществлен автором статьи.
} 
3. Самой распространенной собакой у монголоязычных народов был банхар - одна из самых древних пород, являющаяся верным спутником кочевников во время охоты. Характерной особенностью шерсти собаки является ее бархатистость. Окрас шерстного покрова большей частью черный с подпалинами бурого, желтого, медного или рыжего цветов. Это означает, что охотничья собака монгольской породы не могла быть чисто черного цвета, она имела сложную многоцветную окраску, и скорее всего она была черно-бурого цвета. Г. Й Рамстедт в немецком варианте дает дословный перевод лексемы хар словом schwarz 'черный':

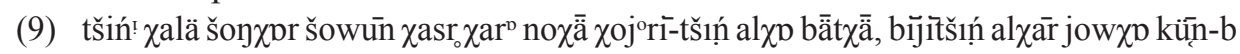
= Чини халә шоңхр шовун хаср хар нохә хойричн алх бәәтхә, бәәтхә, бийичн алхар йовх күнб 'Не только твоих кречет-птицу и охотничью черную собаку убить, но и тебя самого убить я собираюсь!' - Nicht genug damit, dass ich deinen jagdfalken und deinen schwarzen jagdhund getötet habe, ich bin ausgezogen, um dich selbst zu töten! 'Недостаточно того, что я убил твоего кречета и твою черную охотничью собаку, но и тебя самого убить я собираюсь!' [Калмыцкие сказки 2018: 99].

4. Как отмечено в «Атласе пресноводных рыб», щука имеет обычно бурый цвет с поперечными серо-зелеными или белыми полосами [Атлас 2003: 178]. По сюжету сказки сестра Хала Хоогош, имеющая двух братьев (Марс Хар и Гинде Цаган), пытается избавиться от них и посылает к братьям своих людей [Калмыцкие сказки 2018: 267]. В ходе погони происходит несколько превращений как братьев, так и людей, пытающихся убить Марс Хара. Так, богатырь, увидя, что его могут настигнуть враги, превращается в малька и кидается в море. Сторонник сестры превращается в огромную черную щуку для того, чтобы догнать маленькую рыбешку, но это ему не удается. Правильнее в данном случае определять окрас щуки как бурый, но ее связь с хтоническим миром обуславливает наличие черного цвета.

В немецком переводе используется прилагательное schwarz 'черный':

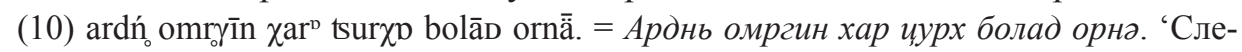
дом огромной черной щукой обернувшись, в море бросилась' — Hinter ihr her stürzt sich [der hund] und wird ein reissender schwarzer hecht. 'Следом бросается за ней [собака] и превращается в быструю черную щуку’ [Калмыцкие сказки 2018: 271].

Интересен и такой момент в данном предложении: в оригинале текста щука - 'огромная черная' (где цвет усиливает связь с Нижним миром, а размер указывает на масштабность этого непознанного и мрачного царства), в немецком же тексте - ‘быстрая черная'. В данном случае переводчик не использует определенные нюансы религиозных воззрений калмыков, а, исходя из контекста сказки, видит процесс погони персонажей сказки, и важным для описания этого процесса является скорость.

5. В оригинале текста на калмыцком языке и в переводе на немецкий язык при обозначении цвета тучи используется прилагательное schwarz 'черный'. Черные тучи в культуре любых народов - это всегда предвестник, беды, несчастья, зла [Соколова 1995: 198; Гревцова 2018: 80]. В контексте данного фольклорного текста лексема $x a p$, и это отмечено в калмыцко-русском слова- 
pe, обозначает грозовое облако [КРС 1977: 577]. В фольклорных текстах тучи обычно имеют эпитет «черный» (явная гиперболизация) и являются предвестником плохого, беды, несчастья:

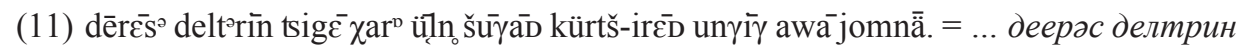
чигә хар ҮҮлн шуугад күрч ирәд, унһиг ава[д] йомнд. '...сверху с подпотник величиной черная туча с шумом налетела и унесла жеребенка' — ...von oben eine schwarze wolke herabgesaust, so gross wie ein sattelpolster, und raubt das fohlen.. '...сверху спустилось черное облако, такое большое, как седло, и похитило жеребенка' [Калмыцкие сказки 2018: 89].

6. Как описывалось выше, кибитки калмыков ишкә гер были покрыты войлоком, цвет которого свидетельствовал о состоятельности хозяина. Черные кибитки хар гер имели простолюдины. Следует отметить, что цвет простой кибитки хар гер не являлся черным. Кошму для кибитки бедняки делали из шерсти овец калмыцкой породы, преобладающим окрасом которых был рыжий цвет. Как отмечает И. А. Житецкий, кибитки покрывались «серо-рыжими кошмами и известны под именем хар гер» [Житецкий 1893: 4]. Кибитки казались черными и потому, что из-за бедности войлок, который должен меняться каждые три-четыре года, использовался часто долгие годы. За это время он становился черным от копоти, неблагоприятных климатических условий, частых латаний.

При переводе предложения:

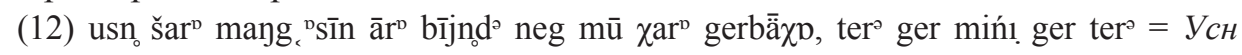
шар мащ̧һсин ар бийнд нег му хар гер бәәх, тер гер мини гер тер 'Позади [жилища] Усун Шара мангасов стоит убогая черная кибитка, эта кибитка и есть мой дом' - Auf der nördlichen seite von dem der gelben Wassermangas steht ein schlechtes, schwarzes zelt, das ist mein haus. 'Позади жилища (букв. на северной стороне) Усун Шара мангасов стоит убогая черная кибитка, эта кибитка и есть мой дом' [Калмыцкие сказки 2018: 371]

- ученый использует при обозначении цвета кибитки прилагательное schwarz 'черный'. В этом же предложении следует отметить правильный перевод словосочетания ар бий 'задняя (тыловая сторона) дома' — die nördliche seite 'северная сторона'. Это свидетельствует о том, что автор хорошо знаком с древней системой ориентации на восход у калмыков, где «север в калмыцкой культуре обозначается как сторона, задняя к стороне полудня» [Бакаева 2009: $20]$.

Таким образом, в текстах Г. Й. Рамстедта найдено и выделено шесть оттенков черного цвета.

\section{Семантика лексемы хар 'черный'}

Лексема хар часто используется при обозначении масти лошадей. Так, в рассматриваемом фольклорном тексте обнаружены три случая употребления лексемы хар при описании масти: хар кер мөрн 'черный гнедой конь'; хар һалзн мөрн 'черный с лысиной конь'; хар маштг 'черный низкорослый’ (конь):

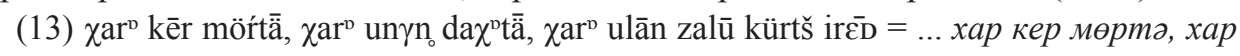
унһн дахтә, хар улан залу күрч ирәд... '...на вороном коне в дохе [из шкуры] вороного жеребенка смуглый мужчина подъехал’ — Unterdessen kam ein 


\section{Монголоведение • Mongolian Studies • 2021 • T. 13 • № 1}

schwarz und roter jüngling mit schwarzem fohlenledernem oberpelz und auf einem dunkelbraunen rosse herangeritten 'Тем временем подъехал смуглый юноша в шубе из жеребячьей кожи на темно-коричневом коне’ [Калмыцкие сказки 2018: 347];

(14) jisn $\chi \mathrm{ar}^{\mathrm{p}} \mathrm{g}$, alzn。 mör! awāD irnā = Йисн хар hалзн мөр авад ирнд... 'Девять черных с лысиной коней привели' - Neun schwarze rosse mit einer blässe am maule holt er herbei ‘Девять черных коней с бледной пастью он привел’ [Калмыцкие сказки 2018: 267];

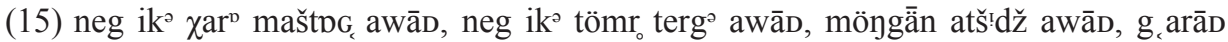
jowdpg bolnä. = Нег ик хар маштг авад, нег ик төмр терг авад, мөнгән ачжс авад, hарад йовдг болнд. 'Одного ширококостного черного низкорослого [коня] купили, одну большую железную телегу купили, деньги свои погрузили и поехали' - Danach kauften sie ein grosses schwarzes pferd und einen hohen eisernen karren, luden darauf das geld und fuhren von da zurück. 'Затем они купили большую черную лошадь и высокую железную тележку, погрузили на нее деньги и поехали обратно’ [Калмыцкие сказки 2018: 249].

Г. Й. Рамстедт дает следующие переводы мастей лошадей: хар кер мөрн 'ein schwarzes Roß mit einer blässe am maule' (букв. 'черный конь с бледностью на носу'), хар һалзн мөрн 'ein dunkelbraunes Roß' (букв. 'темно-коричневый конь'), хар маштг 'ein schwarzes Pferd' (букв. 'черная лошадь').

Как отмечалось выше, черный цвет выступает для характеристики существ Нижнего мира - мусов, шулмусов, мангасов и т. д., которые относятся к фольклорным персонажам и являются «исключительной принадлежностью сказочно-эпической картины мира» монголоязычных народов, так как встречаются только в сказочных текстах [Неклюдов 2019: 241]:

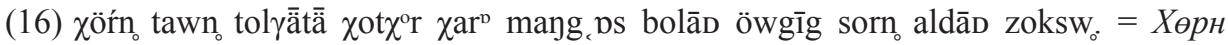
тавн толһәтә хотхр хар маңһс болад, өвгиг сорн алдад зогсв. 'В двадцатипятиголового кривого черного муса [он] превратился и, старика чуть было не проглотив, стоял' - Jener wurde ein senkrückiger, schwarzer Mangas mit fünfundzwanzig köpfen, wollte den mann aussaugen, erreichte ihn nicht und blieb da stehen. 'Тот стал черным мангасом с двадцатью пятью головами, захотел высосать кровь у мужчины, но не достал его и остановился’ [Калмыцкие сказки 2018: 171];

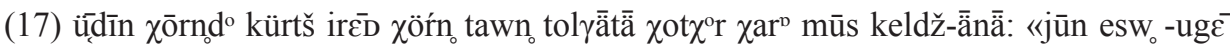
döntä tüšsktā bolāD odw。 -ta? = ҮҮдин [прав. ҮYдн] хоорнд күрч ирәд, хөрн тавн толһәтә хотхр хар мус келжсәна: «Юн эсв угә дөңтә-түшгтә болад одвта? 'К порогу подойдя, двадцатипятиголовый кривой черный мус говорит: «Что за помощника-опору нашли вы себе?»' — Als der fünfundzwanzigköpfige Chotchor Chara Mus zwischen den türpfosten angerückt ist, spricht dieser: "Was für eine grosse stütze und hilfe habt ihr jetzt bekommen? 'Когда двадцатипятиголовый Хотхор Хара Мус приблизился к дверному косяку, говорит этот: «Какую большую поддержку и помощь вы сейчас получаете?' [Калмыцкие сказки 2018: 489].

В немецком тексте Г. Й. Рамстедт использует два варианта перевода лексемы хар - 1) прилагательное schwarz 'черный', 2) без перевода, дает транслитерацию лексемы в качестве онима - Chotchor Chara Mus 'Хотхор Хapa Мус' (букв. кривой черный мус): 


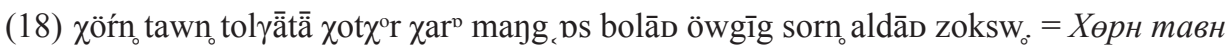
толһәтә хотхр хар маңһс болад, өвгиг сорн алдад зогсв. 'В двадцатипятиголового кривого черного муса [он] превратился и старика чуть было не проглотил' - Jener wurde ein senkrückiger, schwarzer Mangas mit fünfundzwanzig köpfen, wollte den mann aussaugen, erreichte ihn nicht und blieb da stehen. 'Тот превратился в кривого черного мангаса, захотел высосать кровь у старика, но не настиг его и остановился здесь' [Калмыцкие сказки 2018: 171];

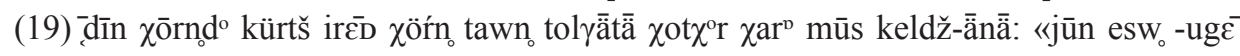
döntä tüšıtä bolāD odw。-ta?»= = Үдин [прав. ҮYдн] хоорнд күрч ирәд, хөрн тавн толһәтә хотхр хар мус келжсәнә: «Юн эсв угә дөңтә-түшгтә болад одвта?» 'К порогу подойдя, двадцатипятиголовый кривой черный мус говорит: «Что за помощника-опору нашли вы себе?»' — Als der fünfundzwanzigköpfige Chotchor Chara Mus zwischen den türpfosten angerückt ist, spricht dieser: "Was für eine grosse stütze und hilfe habt ihr jetzt bekommen?” ‘Когда двадцатипятиголовый Хотхор Хара Мус приблизился к дверному проему, сказал: «Что за большую опору и помощь вы сейчас получили?»' [Калмыцкие сказки 2018: 489].

С религиозными представлениями калмыков о Нижнем мире связан и фра-

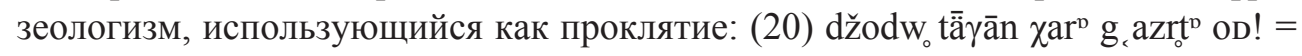
„Жодвтәһан “ хар hазрт од! 'Со своим „Джодво“ сквозь землю провались!' (букв. 'Да провались в черную землю!') — «Scher dich in die hölle mit deinem Dordži-Džodba!» antwortete sie ihm. '«Убирайся в преисподнюю (проваливай в ад) со своим Дорджи Джодба!» - отвечает она ему’ [Калмыцкие сказки 2018: 443].

Наряду с лексемой цุаһан слово хар, как отмечалось выше, обозначает социальное положение человека: хар яста күн 'простолюдин' (букв. 'человек черной кости'), хар күн 'мирянин, простолюдин', хара әмтн 'простые смертные люди':

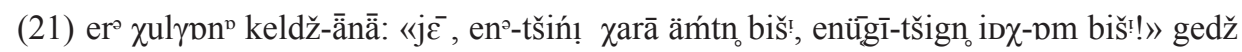
kelnā. = Эр хулһн келжсәнə: «Э, энчн хара әмтн бим, энүгичн идхм биш!»гежс келнд. 'Мышь говорит: «Э-э, он не простой смертный, не будем его есть!» — говорит' - Der mäuschenmann spricht: “Aha, dies ist nicht ein umsonstiges lebewesen. Dies dürfen wir nicht fressen”. 'Мышь говорит: «Э-э, это не прочее живое существо. Этого мы не можем съесть’ [Калмыцкие сказки 2018: 481].

Здесь при переводе на немецкий язык Г. Й. Рамстедт использует выражение sonstiges lebewesen 'прочее живое существо', хотя в немецком языке существует выражение das gemeine Volk 'простонародье, простолюдин'.

Представляет интерес выражение уm хар күн 'букв. длинный черный человек’. Если говорить о росте человека, уместнее было бы использовать слово $и \kappa$ 'высокий' вместо $y m$ 'длинный', словосочетание хар күн означает 'простолюдин'. И в переводе на немецкий язык автор переводит буквально: lange schwarze mann 'букв. длинный черный человек'. Что же означает данное выражение? Явно, что этот персонаж, имеющий один глаз на макушке, олицетворяет зло:

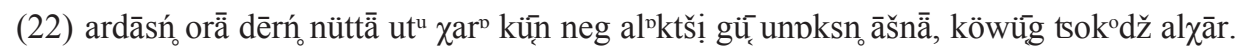
= Ардаснь орә деернь [прав. деерән] нүдтә ут хар күн нег алгч гү унгсн аашнә 
көвүг изожжс алхар. 'Вдогонку за ним с глазом на макушке длинный черный человек на пегой кобыле поскакал, чтобы мальчика убить' - Hinter ihm her nähert sich auf schwarz und weisser stute ein langer, schwarzer mann mit nur einem auge auf dem scheitel, — er nähert sich, um den burschen totzuschlagen. 'Позади него приблизился на черно-белой кобыле длинный черный человек с одним глазом на макушке, он приблизился, чтобы убить мальчика' [Калмыцкие сказки 2018: 407].

Черный человек - это мифологический образ, существующий во многих культурах: черные великаны — в германо-скандинавской мифологии [Мифы 1987: 288], Чернобог - злой бог, приносящий несчастье в мифологии балтийских славян [Мифы 1987: 625], в русских сказках — это один из обликов черта. И в калмыцком фольклоре $y m$ хар күн - это хтонический образ, являющийся представителем Нижнего мира.

При описании внешности человека в тексте встречается выражение хар улан 'букв. черный красный', в предложении его можно перевести как 'смуглый':

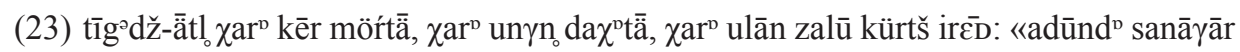

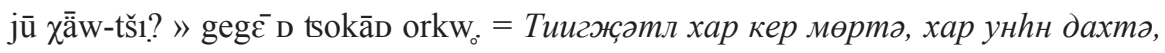
хар улан залу күрч ирәд: «Адунд санаһар ю хәәвч?» - гегед, иокад оркв. 'В это время на вороном коне в дохе [из шкуры] вороного жеребенка смуглый мужчина подъехал. «В табуне что ищешь?» - так сказав, ударил он [его]' Unterdessen kam ein schwarz und roter jüngling mit schwarzem fohlenledernem oberpelz uud auf einem dunkelbraunen rosse herangeritten. 'Между тем пришел красный и черный юноша в черной шубе из кожи жеребенка на темно-коричневом коне' [Калмыцкие сказки 2018: 347].

Но в калмыцком языке для обозначения темного цвета лица существуют только два эквивалента - хар чирәтә 'чернолицый', хар шарвцр 'букв. черно-желтоватый'5. Рассказчик же употребляет выражение хар улан, которого нет в словаре калмыцкого языка. Возможно, это локальное употребление, свойственное данной местности.

Немцы говорят о смуглом человеке - braun 'коричневый', gebräunt 'загорелый', sonnverbrannt 'загорелый'. Переводчик дословно переводит это выражение, не используя слов, употребляемых обычно в немецком языке: schwarz und roter 'красный и черный'.

Цветообозначение хар чаще всего встречается в именах собственных 60 словоупотреблений (42 \% от общего числа употребления колоратива $x a p$ ). Лексема хар является составным элементом антропонимов, встречающихся в фольклорных текстах Г. Й. Расмтедта: Харадә Мергн, Марс Хар баатр, нойн Xap. Данный факт подтверждает, что в культурологическом аспекте черный цвет калмыков имеет неоднозначную коннотацию. Данным эпитетом наделены многие персонажи калмыцких сказок, а именно ханы и богатыри: Хадр Хар Авһ (хан), Хәәрm Хар Күкл (богатырь), Бәрү Хар баатр (богатырь), Күдр Хар (богатырь) [Калмыцкие богатырские сказки 2017: 541-542]. Лексема хар употребляется в качестве эпитета в данных случаях для того, чтобы подчер-

\footnotetext{
${ }^{5}$ Смуглый - «более темной окраски (по сравнению с обычным цветом кожи людей белой расы)» [СРЯ 1961: 222].
} 
кнуть величие и могущество персонажа, т. е. выступает в значении «грозный, могучий».

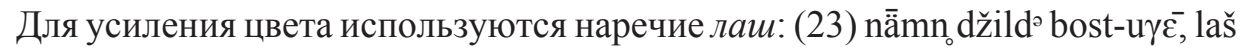
$\chi \operatorname{ar}^{\mathrm{D}}$ keptül̆dž... = Нәәмн жсилд босд[г] угә лаш хар [бууриг] кептүлжс... 'Не встающего восемь лет совершенно черного [верблюда] уложили...' — „Einen acht jahre lang nicht aufstehenden, klotzigen schwarzen kamelhengst (= den grabstein) hat man auf dich gelegt ... 'Не встающего восемь лет очень черного верблюда уложили ...' [Калмыцкие сказки 2018: 275]. В немецком варианте наречию лаш соответствует прилагательное klotzig, 'неуклюжий, неотесанный', но оно может употребляться в разговорной речи и как наречие в значении 'очень'.

\section{Заключение}

Анализ фольклорных текстов Г. Й. Рамстедта показал, что лексема хар может обозначать оттенки цвета от блестяще-черного до серо-рыжего. Не все значения черного цвета, включенные в структуру словарной статьи Калмыцко-русского словаря [КРС 1977: 576-577], найдены в тексте. Лексема хар 'черный' имеет широкую семантику. Лексема хар 'черный’ в своем номинативном значении используется при обозначении цвета предметов (хар кевс 'черный ковер', хар бу 'черное ружье', хар маля 'черная плеть'), масти животных (хар кер мөрн 'черный гнедой конь'; хар һалзн мөрн 'черный с лысиной конь'; хар маштг 'черный низкорослый' (конь)), цвета кожи человека (хар залу 'смуглый мужчина'). В именах собственных он применяется в значении 'крепкий, сильный’ (Марс Хар баатр). Лексема хар 'черный’ может обозначать социальное положение человека: хар яста күн 'простолюдин' (букв. 'человек черной кости'), хар күн 'мирянин, простолюдин', хара әмтн 'простые смертные люди'. В большинстве случаев лексема хар 'черный' имеет отрицательную коннотацию. Черным цветом обозначаются, к примеру, хтонические символы (хар цурх 'черная щука', хар темян 'черный верблюд', уm хар күн 'букв. длинный черный человек'). Во всех приведенных примерах в немецкой части текста автор осуществил переводы лексемы хар, максимально приблизив к калмыцкому тексту.

\section{Литература}

Атлас 2003 - Атлас пресноводных рыб России. В 2 т. / ред. Ю. С. Решетников. Т. 1. М.: Наука, 2003. 379 c.

Бакаева 2009 - Бакаева Э. П. Сакральные коды культуры калмыков. Элиста: ИКИАТ, 2009. $159 \mathrm{c}$.

Гревцова 2018 - Гревцова T. E. Образ Великой Отечественной войны в фольклоре казаков-некрасовцев (по материалам коллекции Ф. В. Тумилевича) // Вестник Академии наук Чеченской республики. 2018. № 5(42). С. 78-82.

Житецкий 1893 - Житецкий И. А. Очерки быта астраханских калмыков. Этнографические наблюдения 1884-1886 гг. М.: Тип. М. Г. Волчанинова, 1893. 75 с.

Жуковская 2002 - Жуковская Н. Л. Кочевники Монголии: Культура. Традиции. Символика. М.: Вост. лит., 2002. 247 с.

Калмыцкие богатырские сказки 2017 - Калмыцкие богатырские сказки. Т. 1. М.: Первая Образцовая типография, 2017. 561 с.

Калмыцкие сказки 2018 - Калмыцкие сказки в записи Г Й. Рамстедта: тексты и исследования. В 3 ч. Ч. ІІ. Переложение и переводы. Элиста: КалмНЦ РАН, 2018. 621 с. 
Кочешков 1973 - Кочешков Н. В. Орнамент монголоязычных народов как исторический источник (в порядке постановки проблемы) // Этнографические вести. Вып. 3. Элиста: КНИИЯЛИ, 1973. С. 3-24.

КРС 1977 - Калмыцко-русский словарь / под ред. Б. Д. Муниева. М.: Русский язык, $1977.754 \mathrm{c}$.

Мифы 1987 - Мифы народов мира. В 2 т. Т. 1. А-К. М.: Сов. энциклопедия, 1987. $671 \mathrm{c}$.

Неклюдов 2019 - Неклюдов С. Ю. Фольклорный ландшафт Монголии. Миф и обряд. М.: Индрик, 2019. 520 с.

Соколова 1995 - Соколова Л. В. Цвет в «Слове» // Энциклопедия «Слова о полку Игореве». В 5 т. Т. 5. СПб.: Дмиртий Буланин. 1995. С. 195-200.

СРЯ 1961 - Словарь русского языка / под ред. С. Г. Бархударова. Т. IV. С-Я. М.: Гос. Изд-во иностр. и нац. словарей, 1961. 1088 с.

Kalmückische 1909 - Kalmückische Sprachproben. Gesammelt und herausgegeben von G. J. Ramstedt. Erster Teil. Kalmückische Märchen. Helsingfors: Societe FinnoOugrienne, 1909. $154 \mathrm{~s}$.

Kalmückische 1919 - Kalmückische Sprachproben. Gesammelt und herausgegeben von G. J. Ramstedt. Zweiter Teil. Kalmückische Märchen. Helsingfors: Societe FinnoOugrienne, 1919. 155-237 s.

\section{References}

Bakaeva E. P. Sacral Codes of Kalmyk Culture. Elista: Institute for the Comprehensive Study of Arid Territories, 2009. 159 p. (In Russ.)

Barkhudarov S. G. (ed.) Dictionary of the Russian Language. Vol. IV: C-Я. Moscow: State Publ. House of Foreign and Soviet National Language Dictionaries, 1961. 1088 p. (In Russ.)

Burykin A. A., Klyaus V. L., Kukanova V. V., Pyurbeev G. Ts. (eds.) Kalmyk Heroic Folktales. B. Mandzhieva (foreword); B. Mandzhieva, T. Mikhaleva, Ts. Seleeva (transl., etc.); B. Mandzhieva, Ts. Seleeva (comments, indices, etc.). Moscow: Pervaya Obraztsovaya Tipografiya, 2017. 561 p. (In Kalm. and Russ.)

Grevtsova T. E. The image of the Great Patriotic War in the Nekrasov Cossacks' folklore (on the materials of the collection of F. V. Tumilevich). Bulletin of the Academy of Sciences of the Chechen Republic. 2018. No. 5(42). Pp. 78-82. (In Russ.)

Kalmyk Folktales Recorded by G. J. Ramstedt. Texts and Studies. In 3 vols. Vol. 2: Transliterations and Translations. Elista: Kalmyk Scientific Center (RAS), 2018. 621 p. (In Kalm. and Russ.)

Kocheshkov N. V. Ornamental patterns of Mongolic peoples as a historical source. In: Ethnographic Messages. Vol. 3. Elista: Kalmyk Research Institute of Language, Literature and History, 1973. Pp. 3-24. (In Russ.)

Muniev B. D. (ed.) Kalmyk-Russian Dictionary. Moscow: Russkiy Yazyk, 1977. 754 p. (In Kalm. and Russ.)

Myths of the World. In 2 vols. Vol. 1: A-K. Moscow: Sovetskaya Entsiklopediya, 1987. 671 p. (In Russ.)

Neklyudov S. Yu. Folklore Landscape of Mongolia: Myth and Ritual. Moscow: Indrik, 2019. 520 p. (In Russ.)

Ramstedt G. J. (comp.) Kalmückische Sprachproben (Kalmyk Speech Patterns). Part One: Kalmyk Folktales. Helsinki: Finno-Ugric Society, 1909. 154 p. (In Germ. and Kalm.)

Ramstedt G. J. (comp.) Kalmückische Sprachproben (Kalmyk Speech Patterns). Part Two: Kalmyk Folktales. Helsinki: Finno-Ugric Society, 1919. 155-237 p. (In Germ. and Kalm.) 
Reshetnikov Yu. S. (ed.) Freshwater Fishes of Russia: Atlas. In 2 vols. Vol. 1. Moscow: Nauka, 2003. 379 p. (In Russ.)

Sokolova L. V. Color in The Tale. In: The Tale of Igor's Campaign. Encyclopedia. In 5 vols. Vol. 5. St. Petersburg: D. Bulanin. 1995. Pp. 195-200. (In Russ.)

Zhitetsky I. A. Astrakhan Kalmyks: Sketches of Everyday Life. Ethnographic Observations of 1884-1886. Moscow: M. Volchaninov, 1893. 75 p. (In Russ.)

Zhukovskaya N. L. Nomads of Mongolia: Culture, Traditions, Symbols. Moscow: Vostochnaya Literatura, 2002. 247 p. (In Russ.) 